\title{
SITUATIONAL LEADERSHIP ON ISLAMIC EDUCATION
}

Oskar Hutagaluh $^{\text {a) }}$, Aslan $^{\text {b) }}$, Purniadi Putra ${ }^{c}$ Abdul Wahab Syakhrani ${ }^{\text {d) }}$, Sri Mulyono ${ }^{\text {e) }}$

a) Antasari UIN Banjarmasin, Dpk. IAIS Sambas, oskarhutagaluh@iaisambas.ac.id

b) Sultan Muhammad Syafiuddin Sambas Islamic Institute, aslanmarani88@yahoo.com

c) Sultan Muhammad Syafiuddin Sambas Islamic Institute, usupurniadi@yahoo.com

d) Rasyidiyah Khalidiyah Amuntai Islamic High School, aws.kandangan@gmail.com

e) Darul Qur'an Institute, Tangerang, srimulyono63@gmail.com

\begin{abstract}
ABSTRAK
Every human being should be a leader both for himself and his family. In reality, not all of human can become leader who are leading the people they lead. This swriting is going to describe the situational leaders who have a leadership style in accordance with the prevailing circumstances of the current rapid social change in the context of islamic education. To explain the situational leadership in islamic education, this paper reviewed various islamic literatures both national and internation cotext. Therefore, the findings of this resaerch were the leadership in islamic intitution is not able to adjust the situation with the current changes. Morever, the Islamic educational institution a leader leads will not be able to compete with the general and Islamic educational institutions that have modernized using the curriculum desired by the government and outside community.
\end{abstract}

Keywords: Islamic Education, Leadership, and Situational Leadership

\section{A. Introduction}

Every human is born with the fitrah (pure) character. This is supported by a hadith that explains that humans are fitrah and that makes him Jewish, Christian and majusi is dependent on their parents which means that if their parents are Muslim, their children will follow the religion of their parents, Islam. The process of forming a religion does not always follow the religion of its parents, when there is environmental influence and peers.

This process aside from being an internal process experienced by the child himself and external factors from environmental influences. ${ }^{1}$ It is from this stage of the process that the selected person is formed, whether it will grow into an ordinary person or a person full of the character of a leader. Leadership implies determining the direction to be followed by others. This direction must not be the origin of the direction, but must be determined by a form of strategic meaning. ${ }^{2}$ Leadership is a process in various ways influencing people or groups of people to achieve a common goal. The leader has the task of exploring the group's needs and desires. From that desire can be drawn realistic desires that can be achieved. Next, the leader must convince the group of what are realistic desires and which are actually imaginary. The

\footnotetext{
${ }^{\mathrm{l}}$ M. Sayyid Muhammad Az-Za'balawi, Pendidikan Remaja Antara Islam dan Ilmu Jiwa. Terj. Abdul Hayyie al-Kattani, Uqinu Attaqi, dan Mujiburrahman Subadi (Jakarta: Gema Insani Press, 2007).

${ }^{2}$ Susilo Supardo, Kepemimpinan Dasar-Dasar dan Pengembangannya (Yogyakarta, 2006), 51-53.
} 
leader's task will succeed well if every leader understands the task that must be carried out. Therefore leadership will appear in the process where someone directs, guides, influences and or controls the thoughts, feelings or behavior of others.

The leader is concerned with power, but is carried out to have a positive impact on his subordinates, because power is used arbitrarily, it will be fatal for subordinates. Subordinates will rebel against their superiors, resulting in conflict.

Thus, for success in achieving goals requires a professional leader, where he understands his duties and obligations, his role as a leader. Besides that the leader must establish a good cooperative relationship with subordinates, so as to create a working atmosphere that makes subordinates feel safe, peaceful, and have a freedom in developing their ideas in order to achieve the common goals that have been set. In addition, leaders have personal abilities. Skills gained and education and environment. After that it can be seen from the position where in this factor even though someone has a good ability, but if he does not have a good position, then his ability in leadership is also limited. And the last is the situation and conditions that can affect leadership where a leader must be able to place his leadership style based on the existing situation in his environment so that the goals in the organization can run well and in accordance with what is desired, including in terms of Islamic education leadership.

Similarly, leadership in Islamic education is a leader in administrative matters by creating a vision, mission for the advancement of educational institutions, with subordinates led are educational staff working in these educational institutions. This paper wants to discuss leadership in situational Islamic education, which means that leadership is influenced by internal and external formation.

The study is literature from collecting various kinds of journals, both national and international, books and other documents that are used as a reference. ${ }^{3}$ References are examined in such a way as possible in accordance with the discussion to be discussed to answer the formulation of the problem that has been made.

\section{B. The Situational Islamic Education Leadership}

Leadership is the main and first root cause of activities, processes or willingness to change views or attitudes (mental, physical) of groups of people, both in formal and informal organizational relationships. Islamic leadership means how the teachings of Islam give style and direction to the leader, and with his leadership is able to change the views or mental attitudes that have been considered to hinder and suffer from a group of people and individuals. But the ability of a leader in his leadership is not caused by just one factor. The success of a leader in leading can be influenced both from within himself and from his

\footnotetext{
${ }^{3}$ Aslan, "Pumping Teacher dalam Tantangan Pendidikan Abad 2l" 2, nomor 2 (2017): 89-100.
} 
environment, as well as the failure of a leader can be influenced by the environment or indeed from within himself.

The leader is a person who has skills and strengths, especially skills / strengths in one area so that he is able to influence other people to jointly carry out certain activities in order to achieve one or several goals. ${ }^{4}$ The concept of success in leadership is essentially related to the level of caring of a leader involved in both orientations, namely what has been achieved by the organization (organizational achievement) and fostering the organization (organizational maintenance). ${ }^{5}$ Although, the level of success of leadership is influenced by several factors and some opinions that have been conducted by the study, by looking at leadership from various perspectives.

Ordway Tead, leader people, because: (1) Forming oneself (self constituded leader, self mademan, born leader). (2) Chosen by the group, meaning that he became a leader because of his services, because of his skills, courage and so on the organization. (3) Appointed from above, meaning that he becomes a leader because he is trusted and approved by his superiors. ${ }^{6}$

Thus, educational leadership is the ability of an educational leader to be able to mobilize all educational resources, both human and non-human resources, to be mobilized, fostered, and directed in carrying out their duties and responsibilities optimally until they are able to realize the stated educational goals.

Human resources, is important for the progress of an institution. ${ }^{7}$ Humans are an important urgency, because without humans, institutions will not progress, despite the technological sophistication they have. Humans are the most urgent resources in supporting the progress of institutions that are supported by technology. ${ }^{8}$

To create superior resources in the current era of globalization, it is not enough just to undergo formal education, but also related to the formation of a good personality in accordance

\footnotetext{
${ }^{4}$ Kartini Kartono, Pemimpin dan Kepemimpinan (Jakarta: Rajawali Press, 1984), 181.

${ }^{5}$ Wahyu Sumijo, Kepemimpinan Kepala Sekolah: Tinjauan Teoritik dan Permasalahannya (Jakarta: Raja Grafindo Persada, 2005), 49.

${ }^{6}$ Imam Mujiono, Kepemimpinan dan Keorganisasian (Yogyakarta: UII Press, 2002), 18.

${ }^{7}$ Oskar Hutagaluh dan Aslan, "Pemimpin dan Pengaruh Geo Politik Terhadap Lahirnya Sumber Daya Manusia Yang Berkarakter," Jurnal Studi Islam Lintas Negara 1, no. 2 (2019): 23-29. Hadi Peristiwo, "Paradigma Manajemen Sumber Daya Manusia Berbasis Spiritual (Spiritual Based Human Resources Management) Terhadap Korporasi," Jurnal Islamiconomic 6, no. 1 (2015): 15-24. Darmadi, Manajemen Sumber Daya Manusia Kekepalasekolahan "Melejitkan Produktivitas Kerja Kepala Sekolah dan Faktor-Faktor yang Memengaruhi" (Yogyakarta: Deepublish, 2018). Rukiaty Usman, "Manajemen Sumber Daya Manusia Strategik, Kinerja Karyawan dan Kinerja Pemasaran (Pada Industri Pengolahan buah markisa di Makassar)," Jurnal Ilmiah agribisnis dan Perikanan (agrikan UMMU-Ternate) 5, no. 2 (2012): 54-60.

${ }^{8}$ Nyoto, Buku Ajar Manajemen Sumber Daya Manusia (Ponorogo, Indonesia: Uwais Inspirasi Indonesia, 2019), 1. Sri Larasati, Manajemen Sumber Daya Manusia (Yogyakarta: Deepublish, 2018), 1. Marihot Tua Efendi Hariandja, Manajemen Sumber Daya Manusia: Pengadaan, Pengembangan, Pengkompensasian, dan Peningkatan Produktivitas Pegawai (Jakarta: Grasindo, 2002), 1. Edy Soetrisno, Manajemen Sumber Daya Manusia (Jakarta: Kencana, 2017), 1. Sukmawati Marjuni, Manajemen Sumber Daya Manusia (Makasar: CV. Sah Media, 2015), 1-2. I. Gusti Ketut Purnaya, Manajemen Sumber Daya Manusia (Yogyakarta: Penerbit Andi, 2016), 3-4.
} 
with the values of Islamic principles. Therefore, important factors influencing the leadership include:

\section{The Situation Factors}

The situation is a condition that surrounds leadership behavior. When the situation is uncertain and chaotic it will be more effective if a charismatic leader is present. If the needs of the organization are difficult to progress because members of the organization who are not progressive personalities then need transformational leaders. If the identity of the organization to be imaged is religious, then the presence of leaders who have spiritual leadership abilities is very significant. That's the situation of speaking, he also sort and choose the abilities of leaders, whether he is present at the right time or not. In a particular situation, sometimes we are required to act quickly and reflexively to solve it. Therefore, the conducive situation between superiors and subordinates must be strengthened with each other in order to always be comfortable and conducive.

The effectiveness of leadership also depends on the pattern of relationships constructed by the leader. The relationship between leaders and followers (teachers and employees) becomes dynamic if the leadership pattern used is participatory. Planning up to all decisions taken by the participatory has positive implications for the level of participation of subordinates. ${ }^{9}$ In addition to the factors that influence someone to become a leader, there are also factors of success for someone to become a leader that is moral. Morale is the state of one's soul and emotions that influences the willingness to carry out tasks and will affect the results of carrying out individual or organizational tasks. Factors that influence it are superior leadership, trust and confidence in truth, respect for task completion, organizational solidarity and pride, education and training, welfare and recreation, opportunities to develop talent, organizational structure and outside influences.

\section{Discipline}

Discipline is obedience without hesitation and is sincere about orders or instructions from superiors and applicable regulations. The best discipline is discipline that is based on personal discipline.

\section{Korsa soul}

The korsa soul is loyalty, pride and enthusiasm that is embedded in members including their leaders towards their organization. In an organization that has a high korsa soul, subordinate dissatisfaction can be extinguished by the spirit of the organization.

\footnotetext{
${ }^{9}$ Rohmat, Kepemimpinan Pendidikan:Konsep dan Aplikasi (Purwokerto: STAIN Purwokerto Press, 2010), 142.
} 


\section{Skill}

Skill is the ability to carry out tasks with good results in a short time by using energy and facilities as efficiently as possible and takes place in an orderly manner. Knowledge and skills possessed by leaders can be obtained from education, training, initiatives and personal development and experience of assignments. ${ }^{10}$

According to Hadari Nawawi, "l the elements in leadership are: the existence of someone who functions to lead, called a leader (leader), the presence of others who are led, the activities that move others carried out by influencing and directing their feelings, thoughts, and behavior and there are objectives to be achieved and take place in a process within the organization, both large and small organizations.

\section{Environmental and Default Factors}

One of the factors that influence individual development is the factor of being born from birth or based on heredity, such as: constitution and physical structure, potential skills (talent and intelligence). Unlike environmental factors, heredity in general tends to be natural which is difficult to modify.

Heredity is a factor of individual genetic makeup. Furthermore, the factors which gave a significant influence include; First, the environment. ${ }^{12}$ The family environment has an important role in realizing the child's personality. Both parents are role players to realize one's personality, both pre-natal environment and post-natal environment is a problem that can not be denied, especially the family environment. The family environment is the first school for children. ${ }^{13}$ Second, school. The school is a formal educational institution that systematically carries out guidance, teaching and training programs in order to help students to be able to develop their potential optimally, both concerning moral-spiritual, intellectual, emotional, social and physical-motoric aspects. Third, peers. Peer groups as a social environment for children have an important role for their development.

Through peer groups, children can meet their needs to learn to interact socially (communicate and cooperate), learn to express the opinions and feelings of others, learn about group norms, and obtain social recognition and acceptance. Fourth, society. Community environment can play a role in shaping the character of children. Fifth, mass media. Mass

\footnotetext{
${ }^{10}$ Ardiprawiro, Teori Organisasi Umum (Universitas Gunadarma, 2014), 24-25.

${ }^{1 l}$ Hadari Nawawi, Manajemen Sumber Daya Manusia: Untuk Bisnis Yang Kompetitif (Yogyakarta: Gajah Mada University Press, 2003), 70.

${ }^{12}$ Robbins dkk., Perilaku Organisasi (Jakarta: Salemba Empat, 2008), 126-27.

${ }^{13}$ Aslan, "Pendidikan Remaja Dalam Keluarga Di Desa Merabuan, Kalimantan Barat (Perspektif Pendidikan Agama Islam)," Al-Banjari 16, no. 2 (2017): 99-112. Kamrani Buseri, Pendidikan Keluarga Dalam Islam Dan Gagasan Implementasinya (Yogyakarta: Lanting Media Aksara Publishing House, 2010). Baihaqi, Pendidikan Agama Dalam Keluarga Bagi Anak Prenatal. Ed., Ahmad Tafsir (Bandung: PT. Remaja Rosda Karya, 2000).
} 
media is an environmental factor that can change or influence people's behavior through processes. Mass media also has a great influence on a person's development, with the mass media, a child can experience a period of growth and development rapidly. Mass media can change a person's behavior in a positive and negative direction, such as television. Television as an electronic mass media has a mission to provide information, education and entertainment to its viewers.

\section{Conclusions}

Leadership is a process in various ways influencing people or groups of people to achieve a common goal. The success or failure of a leader in his leadership is not caused only by one or two factors. in fact, there are many factors both internal and external that can affect one's leadership. The more positive factors that enter a leader, the closer he is to success and vice versa the more negative factors that enter him, the closer he is to the brink of failure.

Thus it can be concluded, that every organization must need a leader, while leadership basically does not always have to be implemented in an organization. Thus it means that the organization will only be able to realize its objectives, if everyone occupies a leadership position in the organization trying to carry out their duties and carry out their leadership effectively in accordance with their respective positions. The duty of a leader is not only to work in accordance with the rules and regulations that are scheduled, more than that, he has an obligation to maintain the organization to continue to exist and run and develop in accordance with environmental conditions / times. Especially with regard to educational leadership that must be prepared to plan, manage subordinates in accordance with the duties of a leader and not violate Islamic religious teachings.

\section{Reference}

Ardiprawiro. Teori Organisasi Umum. Universitas Gunadarma, 2014.

Aslan. "Pendidikan Remaja Dalam Keluarga Di Desa Merabuan, Kalimantan Barat (Perspektif Pendidikan Agama Islam).” Al-Banjari 16, no. 2 (2017): 99-112.

___ "Pumping Teacher dalam Tantangan Pendidikan Abad 2l" 2, nomor 2 (2017): 89-100.

Az-Za'balawi, M. Sayyid Muhammad. Pendidikan Remaja Antara Islam dan Ilmu Jiwa. Terj. Abdul Hayyie alKattani, Uqinu Attaqi, dan Mujiburrahman Subadi. Jakarta: Gema Insani Press, 2007.

Baihaqi. Pendidikan Agama Dalam Keluarga Bagi Anak Prenatal. Ed., Ahmad Tafsir. Bandung: PT. Remaja Rosda Karya, 2000.

Buseri, Kamrani. Pendidikan Keluarga Dalam Islam Dan Gagasan Implementasinya. Yogyakarta: Lanting Media Aksara Publishing House, 2010.

Darmadi. Manajemen Sumber Daya Manusia Kekepalasekolahan "Melejitkan Produktivitas Kerja Kepala Sekolah dan Faktor-Faktor yang Memengaruhi." Yogyakarta: Deepublish, 2018.

Hariandja, Marihot Tua Efendi. Manajemen Sumber Daya Manusia: Pengadaan, Pengembangan, Pengkompensasian, dan Peningkatan Produktivitas Pegawai. Jakarta: Grasindo, 2002.

Hutagaluh, Oskar, dan Aslan. "Pemimpin dan Pengaruh Geo Politik Terhadap Lahirnya Sumber Daya Manusia Yang Berkarakter.” Jurnal Studi Islam Lintas Negara 1, no. 2 (2019): 23-29. 
Hutagaluh, Oskar, et al. "Responsive Leadership in Preventing Transmission of Covid-19 in the Indonesia-malaysia Border Area." (2020).

Kartono, Kartini. Pemimpin dan Kepemimpinan. Jakarta: Rajawali Press,1984.

Larasati, Sri. Manajemen Sumber Daya Manusia. Yogyakarta: Deepublish,2018.

Marjuni, Sukmawati. Manajemen SumberDaya Manusia. Makasar: CV. Sah Media,2015.

Mujiono, Imam. Kepemimpinan dan Keorganisasian.Yogyakarta: UII Press,2002.

Nawawi, Hadari.Manajemen Sumber Daya Manusia: Untuk Bisnis Yang Kompetitif. Yogyakarta: Gajah

Mada University Press, 2003.

Nyoto.Buku Ajar Manajemen Sumber Daya Manusia. Ponorogo, Indonesia: Uwais Inspirasi Indonesia, 2019.

Peristiwo, Hadi. -Paradigma Manajemen Sumber Daya Manusia Berbasis Spiritual (Spiritual Based Human Resources Management) Terhadap Korporasi.॥ Jurnal Islamiconomic 6, no. 1 (2015):

$15-24$.

Purnaya, I. Gusti Ketut. Manajemen Sumber Daya Manusia. Yogyakarta: Penerbit Andi,2016.

Robbins, Stephen P, Judge, dan Timothy A. Perilaku Organisasi. Jakarta: Salemba Empat,2008.

Rohmat. Kepemimpinan Pendidikan: Konsep dan Aplikasi. Purwokerto: STAIN Purwokerto Press,2010.

Soetrisno, Edy. Manajemen Sumber Daya Manusia. Jakarta: Kencana, 2017.

Sumijo, Wahyu.Kepemimpinan Kepala Sekolah: Tinjauan Teoritik dan Permasalahannya.Jakarta: Raja Grafindo Persada, 2005.

Supardo, Susilo. Kepemimpinan Dasar-Dasar dan Pengembangannya. Yogyakarta,2006.

Usman, Rukiaty.-Manajemen Sumber Daya Manusia Strategik, Kinerja Karyawan dan Kinerja Pemasaran (Pada Industri Pengolahan buah markisa di Makassar).॥jurnal Ilmiah agribisnis dan Perikanan (agrikan UMMU-Ternate) 5, no. 2 (2012): 54-60. 